\title{
Depleted uranium and public health risks in the Balkan region
}

\author{
F. P. Carvalho \\ Instituto Tecnológico e Nuclear, \\ Departamento de Protecção Radiológica e Segurança Nuclear, Portugal
}

\begin{abstract}
The use of ammunition made of depleted uranium (DU) in the Balkans' war raised concerns about environmental contamination and toxic effects of DU in humans. Since 2000, investigations performed in that region concluded that there is local contamination but no widespread environmental contamination with DU. Soils, agriculture, and drinking water supplies were not compromised with DU contamination. Although there are concerns related to the environmental fate of ammunition left in the battlefield, analyses of foods and uranium bioassay in human urine samples indicated that uranium concentrations generally are similar to background levels in the Balkans and elsewhere in Europe. DU in the Balkan region does not represent a health hazard in most of the territory and to the general population. However, areas contaminated with DU justify monitoring and surveillance to avoid occasional contamination of members of the public.
\end{abstract}

Keywords: depleted uranium, environmental contamination, soil, agriculture, drinking water, foods, urine bioassay, humans.

\section{Depleted uranium: characteristics and uses}

Uranium is the heaviest naturally occurring element in nature represented by three isotopes in nearly constant proportions, being ${ }^{238} \mathrm{U}$ the most abundant (Table 1). Uranium is mined from geological deposits primarily for use as fuel in nuclear power plants. However, to optimize the nuclear chain reaction the small percentage of naturally occurring ${ }^{235} \mathrm{U}, 0.72 \%$, is enriched usually to about $4-5 \%$. The ${ }^{235} \mathrm{U}$ enriched uranium is used as nuclear fuel and the ${ }^{235} \mathrm{U}$ impoverished uranium is a by-product called depleted uranium (DU) [1]. As the DU world stocks are large, DU has been used in several applications when the uranium 
metal properties are an advantage compared to other metals. For example, DU has been applied in keels of sailing ships and counter-weights for flaps in aircrafts, as a radiation shield in special containers, and as armor in tanks. The same properties that make it special as a shield, advised its use in ammunition against armored vehicles (penetrators, $5-7 \mathrm{~kg}$ each) or as ammunition used in air strikes against ground targets (25 and $35 \mathrm{~mm}$ rounds, 200-300 g each). From the physical point of view DU has not the same isotopic composition, but it is has the same chemical characteristics and it is $40 \%$ less radioactive than natural uranium (Table 1).

Table 1: $\quad$ Composition of natural uranium and depleted uranium.

\begin{tabular}{|l|l|l|l|l|l|l|}
\hline & & \multicolumn{2}{|l|}{ Natural uranium } & \multicolumn{2}{|l|}{ Depleted uranium } \\
\hline Isotopes & $\begin{array}{l}\text { Half-life } \\
(\mathrm{y})\end{array}$ & $\begin{array}{l}\text { Abundance } \\
(\%)\end{array}$ & $\begin{array}{l}\text { Activity } \\
(\%)\end{array}$ & $\begin{array}{l}\text { Abundance } \\
(\%)\end{array}$ & $\begin{array}{l}\text { Activity } \\
(\%)\end{array}$ \\
\hline${ }^{238} \mathrm{U}$ & $4.468 \times 10^{9}$ & 99.2745 & 48.9 & 99.799 & 84.7 \\
\hline${ }^{235} \mathrm{U}$ & $7.038 \times 10^{8}$ & 0.7200 & 2.2 & 0.200 & 1.1 \\
\hline${ }^{234} \mathrm{U}$ & $2.444 \times 10^{5}$ & 0.0055 & 48.9 & 0.001 & 14.2 \\
\hline Isotope ratios & Mass & Activity & Mass & Activity \\
\hline${ }^{235} \mathrm{U}{ }^{238} \mathrm{U}$ & 0.00725 & 0.045 & 0.002 & 0.0129 \\
\hline${ }^{234} \mathrm{U} /{ }^{238} \mathrm{U}$ & $5.5 \times 10^{-5}$ & 1.0 & $1.00 \times 10^{-5}$ & 0.167 \\
\hline $\begin{array}{l}\text { Specific activity } \\
\text { of } 1 \mathrm{mg}\end{array}$ & & $25.28 \mathrm{~Bq}$ & & $14.66 \mathrm{~Bq}$ \\
\hline
\end{tabular}

\section{DU in the Balkan conflict}

Following the disintegration of the former Yugoslavian Republic and conflicts therein, in 1995-6 ammunition with DU projectiles were used in the battlefield in Bosnia Herzegovina (BiH). Again in 1999, were fired rounds of DU ammunition in Kosovo. Total amounts were estimated at 3 and 10 tons of DU, fired respectively in $\mathrm{BiH}$ and Kosovo $[1,2]$. The international press had expressed views that leukemia cases amongst the NATO military staff in the Balkans and amongst populations were increasing due to DU exposure. DU ammunition had previously been used in the Gulf War in Iraq and it was known that several soldiers were under medical surveillance after having been wounded with DU shrapnel and inhaled DU fine dust that is formed following the volatilization of these ammunition when they hit hard surfaces [1]. The rising concerns in the public opinion of European countries, many amongst them contributing to the peace-keeping forces in the Balkans, motivated several scientific missions to investigate the contamination of the Balkan region and exposure of the military and of the populations to DU [3].

Questions such as the radioactivity added to the environment by the DU ammunition, the exposure to depleted uranium and chemical toxic effects on 

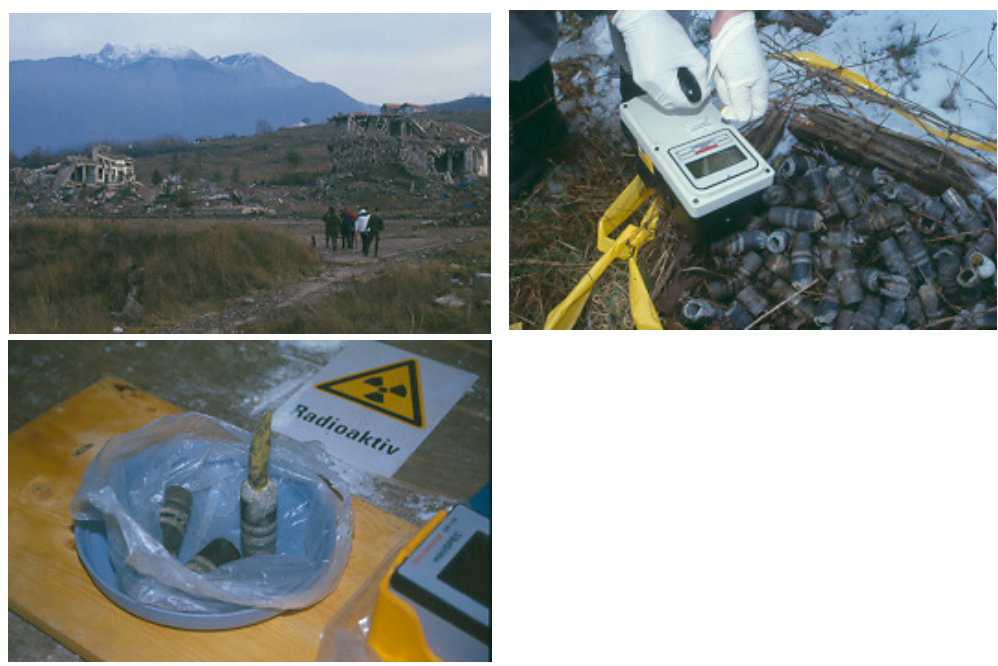

Figure 1: $\quad$ Monitoring bombed sites in Kosovo and DU rounds found on the ground.

humans, the presence of artificial radionuclides such as plutonium in the ammunition, and the widespread contamination of the Balkan region with DU were the key issues to investigate.

One of the first reports produced on DU in the Balkan region, published by ITN/DPRSN, gave a very detailed account of the external radiation doses from thorough monitoring of hundreds of spots in Bosnia Herzegovina and in Kosovo and of radionuclides in samples collected for analysis in the laboratory [3]. The results reported by the Portuguese scientific mission, as well as by the UNEP mission, were followed by studies performed by the IAEA, Germany, Italy, France, and others [4]. In general, their conclusions were in agreement and confirmed that there was no significant increase in the environmental radiation in those territories. In the following years reports of analytical results rendered known the exact concentrations of radionuclides in soils, lichens, tree bark, water samples, aerosols, foods, and even humans allowing building up a clear picture of the situation.

\section{DU in the environment}

Field missions reported the finding of DU projectiles on the ground at several heavily shelled targets in Kosovo. The measurement of external radiation confirmed that they were made of uranium. The analysis of this metal by several techniques confirmed that it was DU, with traces of an artificial isotope ${ }^{236} \mathrm{U}$ $\left(2.8 \times 10^{-3} \%\right)$ and sometimes with traces of $\mathrm{Pu}$ also [2]. No presence of fission products was detected. The several missions concluded that there was no use of such a "radiological weapon" as radioactive waste (spent nuclear fuel) in the 
rounds fired in the Balkans, although reprocessed uranium might have been used in the manufacture of DU ammunition (Fig 1).

Soil samples were analyzed in several laboratories using techniques such as gamma spectrometry, alpha spectrometry and mass spectrometry. Soil samples collected in bombed sites displayed higher $U$ concentrations with ${ }^{235} U /{ }^{238} U$ isotopic ratios lowered due to contamination with DU. However, it was clear that the DU contamination was limited to the sites of ammunition impact and could not be detected at short distance from impact points [2, 3, 5]. Samples collected in the soil layers under the impact holes were obviously contaminated, and some laboratories focused on the investigation of DU behaviour in these small contaminated spots. Other laboratories focused on the monitoring of soils across the region. Thorough analyses of soil samples from agriculture and urban areas showed no DU contamination but the naturally occurring uranium with natural isotopic ratios only $[3,6]$. Therefore soils and agriculture were not compromised.

Rounds that impact hard targets (e.g., concrete walls or metal surfaces) ignite and DU is vaporized forming a uranium oxide fine dust that spreads around. Evidence for this was provided by the analyses of lichens and tree bark which contained enhanced $U$ concentrations and modified isotopic ratios in several bombed areas (Table 2). Indeed in many places where the DU was not detected in surface soils anymore, the analyses of lichens, that are known to preserve the atmospheric signals for several years, clearly showed DU dust dispersed in the area. This DU signal was certainly from the battlefield and once the DU dust settled the mobility of DU has probably been very limited. Indeed in January 2001 , one scientific mission displayed large volume air samplers at several cities to collect air dust in surface air. Results of the analysis of filters showed that there was no DU in the aerosol, although uranium isotopes and even ${ }^{137} \mathrm{Cs}$ could be measured. These radionuclides were from re suspension of soil dust where $U$ isotopes are ubiquitous and ${ }^{137} \mathrm{Cs}$ is present from radioactive fallout originated in the nuclear weapons tests and Chernobyl accident $[3,7]$.

DU projectiles abandoned in and on the ground and oxide dust originated in projectile ignition could compromise vital resources, such as river water and groundwater used for supplying the population with drinking water. Therefore, it was a key issue to check the DU contamination of water resources. Analyses of river water and tap water in the main cities revealed no contamination with DU [3]. All these waters contained natural uranium in concentrations that meet the WHO requirements for drinking water regarding uranium, i.e., were lower than $2 \mu \mathrm{g} / \mathrm{L}$ [9]. One laboratory reported however that water from two wells in the countryside, near a shelled site, showed traces of DU in solution [5]. This was attributed to DU projectiles that could be corroding in the soil nearby or even inside the wells.

\section{DU in the food chain}

Analyses of foods consumed in the region and especially foods of local production in the Balkans were more rarely performed. One laboratory reported results for meat, cheese, milk, cabbage, fruits and bread from local production in 
$\mathrm{BiH}$ and Kosovo. Results were generally DU negative and total uranium concentrations were similar to concentrations measured in foods produced elsewhere in Western Europe countries [9]. There were traces of DU contamination in bread manufactured in $\mathrm{BiH}$ and Kosovo that was attributed to DU dust dispersal on the crops in the previous year. Altogether the uranium concentrations in food were not significantly increased by DU and the uranium dietary intake would not be significantly modified. It should be pointed out that the average uranium intake is estimated at $15 \mu \mathrm{g} \mathrm{U}$ per person per day [1]. The contamination with DU in Bosnia and in Kosovo had not increased that natural amount in more than 5\% in the year 2001 .

Table 2: Concentrations and activity isotope ratios in samples from the Balkan region.

\begin{tabular}{|c|c|c|c|c|}
\hline Soils & $\begin{array}{l}{ }^{238} \mathrm{U}^{-1}(\mathrm{dw}) \\
\mathrm{Bq} \mathrm{kg}^{-1}\end{array}$ & $\begin{array}{l}{ }^{235} \mathrm{U} /{ }^{238} \mathrm{U} \\
\text { Ratio }\end{array}$ & $\begin{array}{l}{ }^{239+240} \mathrm{Pu} \\
\mathrm{Bq} \mathrm{kg}^{-1}(\mathrm{dw})\end{array}$ & Ref \\
\hline \multirow[t]{2}{*}{ Kosovo } & $\begin{array}{l}\text { Background } \\
14-36\end{array}$ & & & {$[5]$} \\
\hline & $\begin{array}{l}\text { Contaminated } \\
\text { up to } 54 \times 10^{3}\end{array}$ & & & {$[5]$} \\
\hline \multirow[t]{2}{*}{ Kosovo } & $\begin{array}{l}\text { Background } \\
9-34\end{array}$ & 0.049 & $9 \times 10^{-4}$ & {$[3]$} \\
\hline & $\begin{array}{l}\text { Contaminated } \\
\text { up to } 4.7 \times 10^{3}\end{array}$ & $0.015-0.024$ & & {$[3]$} \\
\hline $\begin{array}{l}\text { Bosnia } \\
\text { Herzegovina }\end{array}$ & $13-56$ & 0.050 & $0.1-0.5$ & {$[3]$} \\
\hline Kosovo & & & $0.02-1$ & [7] \\
\hline Water & $\begin{array}{l}{ }^{238} \mathrm{U} \\
\mathrm{mBq} / \mathrm{L}\end{array}$ & $\begin{array}{l}{ }^{235} \mathrm{U} \\
\mathrm{mBq} / \mathrm{L}\end{array}$ & $\begin{array}{l}{ }^{235} \mathrm{U} /{ }^{238} \mathrm{U} \\
\text { Ratio }\end{array}$ & \\
\hline $\begin{array}{l}\text { Serbia and } \\
\text { Montenegro }\end{array}$ & $0.40-21.9$ & $0.01-088$ & $0.036-0.077$ & {$[8]$} \\
\hline Kosovo & $2.4-9.4$ & $0.1-0.4$ & $0.040-0.065$ & [9] \\
\hline $\begin{array}{l}\text { Bosnia } \\
\text { Herzegovina }\end{array}$ & $0.79-14.8$ & $0.05-0.8$ & $0.029-0.065$ & [9] \\
\hline $\begin{array}{l}\text { Lichens and } \\
\text { tree bark }\end{array}$ & $\begin{array}{l}{ }^{238} \mathrm{U} \text { Bq kg-1 } \\
(\mathrm{dw})\end{array}$ & $\begin{array}{l}{ }^{235} \mathrm{U} \text { Bq kg-1 } \\
(\mathrm{dw})\end{array}$ & $\begin{array}{l}{ }^{235} \mathrm{U} /{ }^{238} \mathrm{U} \\
\text { Ratio }\end{array}$ & \\
\hline $\begin{array}{l}\text { Serbia and } \\
\text { Montenegro }\end{array}$ & $0.67-704$ & $0.02-12.2$ & $\begin{array}{l}0.0051-0.019 \mathrm{~S} \\
0.007-0.204 \mathrm{M}\end{array}$ & {$[8]$} \\
\hline Food & $\begin{array}{l}{ }^{238} \mathrm{U} \mathrm{Bq} \mathrm{kg}^{-1} \\
(\mathrm{ww})\end{array}$ & $\begin{array}{l}{ }^{235} \mathrm{U} \mathrm{Bq} \mathrm{kg}^{-1} \\
(\mathrm{ww})\end{array}$ & $\begin{array}{l}{ }^{235} \mathrm{U} /{ }^{238} \mathrm{U} \\
\text { Ratio }\end{array}$ & \\
\hline Kosovo & $1.4-7.9$ & $0.1-1.1$ & $0.013-0.196$ & {$[3]$} \\
\hline $\begin{array}{l}\text { Bosnia } \\
\text { Herzegovina }\end{array}$ & $1.9-58$ & $0.1-1.6$ & $0.007-0.176$ & [9] \\
\hline
\end{tabular}

Dw, dry weight; ww, wet weight. 


\section{DU in humans}

Uranium analyses were performed in urine samples from military staff of several nationalities and civilians from the local population to assess whether humans were internally contaminated with DU. These studies have made use of different analytical techniques and sampled groups of different size [3, 4, 12]. All concluded that the groups investigated displayed median uranium values in urine that were similar to control groups. Few individuals have shown uranium concentrations slightly elevated and one civilian in Kosovo displayed uranium isotopic ratios in urine indicating DU. Conclusions were that the general population and particularly the military staff were not contaminated with DU. A reduced number of individuals may have been in contact with DU aerosols and could have either inhaled or ingested small quantities of DU. However, in the mass screenings performed there has been no identification of heavily contaminated people. It should be pointed out that amongst the military veterans of Gulf War there are soldiers with relatively high $U$ concentrations in urine but these are cases with DU shrapnel embedded in tissues [12]. DU fragments in the body are slowly dissolved in body fluids and the uranium is excreted with urine. Cases alike do not exist in the Balkan region.

Analyses of uranium in human tissues collected post mortem in the case of military staff that served in the Balkans were reported as well and compared to control cases. No DU was identified [3].

\section{DU biological effects}

DU is chemically similar to natural uranium and has no distinct toxic properties. The toxicity of uranium compounds has been investigated experimentally in animal models for many years and effects on humans were observed also in occupationally exposed groups such as uranium miners and workers of uranium milling facilities. Uranium oxide inhaled may have radiological effects on lungs and on lymph nodes, although the doses involved in DU inhalation generally are not high enough to produce cancer effects. Uranium inhalation and ingestion followed by gastric assimilation into the body tissues may generate chemical toxic effects, being the kidneys the critical organ $[1,12]$. Uranium limits adopted in occupational hygiene to protect workers from the chemical toxicity from uranium were set at $2 \mu \mathrm{g} \mathrm{U} / \mathrm{g}$ kidney [12]. In view of the uranium concentrations measured in food, water and air, and checked with uranium analysis in urine samples, no case of humans significantly contaminated with $U$ have been identified in the Balkans. There are no reasons to believe that these levels may be attained in the Balkans population with the low levels of uranium reported in foods and water. Therefore, no increase in cases of kidney damage in the population should be expected above the incidences from other causes.

\section{Conclusions}

The use of DU ammunition the Balkan's war was confirmed by the analyses of round fragments and confirmed by NATO. There was no environmental spread 
of radioactive waste from the use of spent nuclear fuel in ammunition as feared in the media. Nevertheless, environmental analyzes performed by several European institutes confirmed the dispersion of DU dust in the environment certainly from ammunition that vaporized after hitting hard targets.

Regarding the DU contamination of surface soil layers, soils were carefully monitored in the region and such a widespread contamination did not occur. Therefore, agriculture is not compromised. Water from rivers and water from surface reservoirs and aquifers were analyzed. Both in Bosnia Herzegovina and Kosovo the main supplies of drinking water were not contaminated with DU. However, DU projectiles that penetrated in the ground may dissolve and with time may reach groundwater. The extent of the contamination that this DU may cause is difficult to estimate. This issue was considered sensitive and recommendations for follow up were made.

Contamination of foods with DU was neither widespread nor detectable in most cases. In a few cases there as been foods displaying traces of DU. However, there have been no highly contaminated samples of foods and water identified. The ultimate verification was the uranium bioassay in humans. Results from vast epidemiological campaigns based on the uranium bioassay in human urine samples have shown that there has been no internal DU contamination of humans in the Balkan region by the war time. Furthermore, it seems unlikely that the dispersal of the relatively small amounts of DU in the environment may significantly increase the dietary intake of this element by the local population in the future.

As DU contamination is restricted to heavily shelled but small areas where DU is detectable above the naturally occurring background, the public health risk posed by DU seems much localized. There is no significant enhancement of radioactivity levels and uranium metal levels in the Balkan region that may represent a broad public health hazard in this region. Nevertheless, DU monitoring of the shelled areas was considered advisable in order to prevent contamination of the food chain and, on occasion, members of the public in these areas.

\section{References}

[1] Bleise A., Danesi, P.R. Burkart, W. Properties, use and health effects of depleted uranium (DU): a general overview. J Environ Radioactivity 2003; 64: 93-112.

[2] UNEP. Depleted uranium in Kosovo, post-conflict environmental assessment. United Nations Environmental Programme, Balkans Task Force. Nairobi, 2001.

[3] ITN/DPRSN. Report of the Portuguese Scientific Mission to Kosovo and to Bosnia- Herzegovina for Assessment of Radioactive Contamination and of the Radiological Risk due to the Use of Depleted Uranium Ammunitions. DPRSN-A nº14, ISBN 972-8660-17-0, 5 April 2001. Lisbon; 2001.

[4] GSF. A study of uranium excreted in urine. An assessment of protective measures taken by the German Army KFOR Contingent. GSF Report 3/01, 
GSF-National Research Center for Environment and Health, Institute of Radiation Protection, Neuherberg, Germany; 2001.

[5] Sansone U, Danesi PR, Barbizzi S, Belli M, Campbell M, Gaudino S, Jia G, Ocone R, Pati A, Rosamilia S, Stellato L. Radioecological survey at selected sites hit by depleted uranium ammunition during the 1999 Kosovo conflict. Science of the Total Environment 2001; 281: 23-25.

[6] Uyttenhove J, Lemmens M , Zizi, M, 2002. Depleted Uranium in Kosovo: Results of a survey by gamma spectrometry on soil samples. Health Physics, 83(4), pp. 543-548.

[7] Danesi PR, Bleise A, Burkart W, Cabianca T, Campbell MJ, Makarewicz M, Moreno J, Tuniz C, Hotchkis M. Isotopic composition and origin of uranium and plutonium in selected soil samples collected in Kosovo. J Environ Radioactivity 2003; 64:121-131.

[8] Jia G, Belli M, Sansone U, Rosamilia S, Gaudino S. Concentration and characteristics of depleted uranium in water, air and biological samples collected in Serbia and Montenegro. Applied Radiation and Isotopes 2005; 63(3): 381-399.

[9] Carvalho FP, Oliveira JM. Uranium isotopes in the environment and foods in the Balkan region. (in press).

[10] Jia G, Belli M, Sansone U, Rosamilia S, Gaudino S. Concentration and characteristics of depleted uranium in biological and water samples collected in Bosnia and Herzegovina. J Environ Radioactivity 2006; 89(2):172-187.

[11] Di Lella LA, Frati L, Loppi S, Protano G, Roccobono F. Lichens as biomonitors of uranium and other trace elements in an area of Kosovo heavily shelled with depleted uranium rounds. Atmospheric Environment 2003;37: 5445-5449.

[12] Oeh U, Priest ND, Roth P, Ragnarsdottir KV, Li WB, Hollriegl V, Thirlwall MF, Michalke B, Giussani A, Schramel P, Paretzke H G. Measurements of daily urinary uranium excretion in German peacekeeping personnel and residents of the Kosovo region to assess potential intakes of depleted uranium (DU). Science of the Total Environment 2007; 381(1-3): 77-87. 